\title{
REFORMASI ADMINISTRASI DAN KARAKTER BANGSA : SEBUAH KAJIAN KONSEPTUAL
}

\author{
Bambang Irawan \\ Sekolah Tinggi Ilmu Administrasi Mandala Indonesia \\ bambang.irawan@stiami.ac.id
}

\begin{abstract}
Administrative reform is basically an administrative process improvements on an ongoing basis. As a process, administrative reform has certain goals to be achieved. On the other hand, the character of the nation's understanding of transformation born of cultural values in society can serve as the foundation for the direction of administrative reform a nation. It's intended as a bridge in understanding the interconnection between both concepts.
\end{abstract}

Keywords: Administrative Reforms, National Character, Culture, Transformation Value

Abstrak. Reformasi administrasi pada dasarnya merupakan proses perbaikan administrasi secara terus-menerus. Sebagai sebuah proses, reformasi administrasi memiliki sasaran tertentu yang ingin dicapai. Di sisi lain, pemahaman akan karakter bangsa yang lahir dari transfromasi nilai-nilai budaya yang berkembang di masyarakat dapat dijadikan landasan bagi arah reformasi administrasi suatu bangsa. Tulisan ini dibuat sebagai jembatan dalam memahami keterkaitan kedua konsep tersebut.

Kata Kunci: Reformasi Administrasi, Karakter Bangsa, Budaya, Tranformasi Nilai

Makna reformasi saat ini banyak disalahartikan dan bergeser dari makna sebenarnya. Kerap kali tuntutan yang bertujuan melakukan perubahan yang terjadi di masyarakat mengatasnamakan gerakan reformasi, walaupun berbeda dengan esensi reformasi itu sendiri. Menurut Oxford Advanced Learner's Dictionary of Current English (1980) Reformasi secara etimologis berasal dari kata "reformation" dengan akar kata "reform" yang secara semantik bermakna "make or become better by removing or putting right what is bad or wrong". Secara harfiah reformasi memiliki makna suatu gerakan untuk memformat ulang, menata ulang atau menata kembali hal-hal yang menyimpang untuk dikembalikan pada format atau bentuk semula sesuai dengan nilai-nilai ideal yang dicitacitakan rakyat (Imawan, 1999).

Reformasi merupakan bagian dari dinamika masyarakat. Hal ini terjadi disebabkan perkembangan yang menyebabkan tuntutan terhadap pembaharuan dan perubahan untuk menyesuaikan diri dengan lingkungan yang telah berubah. Reformasi juga bermakna sebagai suatu perubahan tanpa merusak (to change without destroying) atau perubahan dengan memelihara (to change while preserving). Dalam hal ini, proses reformasi bukanlah proses perubahan yang radikal dan berlangsung dalam jangka waktu singkat, tetapi merupakan proses perubahan yang terencana dan bertahap.

Reformasi khususnya dalam bidang administrasi membutuhkan asumsi-asumsi dasar untuk melakukan perubahan. Dalam konteks inilah, uraian berikut secara singkat akan memberikan gambaran bagaimana konsep karakter bangsa menjadi asumsi dasar bagi reformasi administrasi.

\section{Reformasi Administrasi}

Caiden (1969: 65) mendefinisikan reformasi administrasi sebagai "the artificial inducement of administrative transformation, against resistance". Defenisi ini memiliki tiga konsep yang saling terkait, pertama dari sisi tujuan moral, yakni kebutuhan untuk memperbaiki status quo. Kedua, adanya transformasi buatan yang berangkat dari pengaturan yang ada menuju proses perubahan. Dan yang ketiga, resistensi administrasi, Dalam hal ini resistensi diasumsikan ada. Sejalan dengan pendapat Caiden, reformasi 
administrasi pada hakikatnya merupakan proses permanent improvement in administration (Wallis, 1993). Proses tersebut tentunya tidak dapat terjadi begitu saja tanpa ada usaha yang dibangun secara sadar. Sedangkan inti permanent improvement terletak pada kesinambungan usaha dalam waktu yang lama untuk mengarah kepada yang lebih baik.

Proses perbaikan secara terus-menerus dalam konteks administrasi tersebut memiliki beberapa pendekatan, yakni pendekatan proses dan dampak. Pada pendekatan proses, reformasi administrasi lebih fokus pada perubahan dalam proses, prosedur dan hubungan di antara dan sesama administrasi pemerintahan (Peter, 1994 dalam Farazmand, 2002: 126). Farazmand (2002: 3) menyebut pendekatan proses ini sebagai pendekatan Top-Down, dan menjelaskan bahwa model ini mengasumsikan bahwa beberapa aktor-elit, yakni orang-orang yang memiliki kekuasaan atau kewenangan memiliki tujuan tertentu dalam pikiran dalam mengejar reformasi dan reorganisasi. Model ini mengasumsikan bahwa para pemimpin politik memandang masalah atau mengembangkan ideide inovatif melalui reformasi dan reorganisasi sektor publik. Senada dengan itu, Zauhar (2007: 11) lebih spesifik menjelaskan arah reformasi administrasi meliputi struktur dan prosedur, serta sikap dan prilaku yang dilakukan secara sadar dan terencana. Dari dua pendapat di atas, terlihat bahwa penekanan reformasi terletak pada sturktur, lembaga dan prilaku serta birokrasi sebagai locusnya.

Salah satu model Top-Down adalah bentuk administrasi yang bersifat umum, yang paling sering digunakan dalam dunia administrasi publik, yakni kebutuhan yang dirasakan untuk reformasi dan reorganisasi ditentukan di level atas. Menurut Pollitt (Farazmand, 2002: 3), pendekatan ini adalah pendekatan yang tradisional dan pragmatis yang merupakan pendekatan terhadap "seperangkat mesin" dari pemerintah dan bagaimana merubah mesin tersebut.

Pendekatan kedua dalam model top-down ialah pendekatan ilmu politik, dengan alasan politik "ungovernability," pemerintah yang "overload," dan alasan-alasan rasional lainnya dianggap menjadi alasan perubahan dalam pemerintahan yang berdampak terhadap administrasi publik (Pollitt dalam Farazmand, 2002: 4). Akibatnya, pengurangan level manajemen, privatisasi, dan perampingan yang umum digunakan istilah diterapkan oleh purposive, model top-down. meskipun model ini sangat membantu, mereka menganggap bahwa aktor utama dalam proses ini adalah sebagai "pusat identifikasi, seleksi, dan implementasi perubahan administrasi" (Peters, 1994: 112).

Pendekatan lainnya adalah pendekatan dampak yang berorientasi pada penciptaan sistem administrasi sebagai instrumen yang lebih efektif dalam perubahan sosial, kesetaraan politik, keadilan sosial dan pertumbuhan ekonomi (Samonte, 1970: 288). Pendekatan ini oleh Farazmand (2002: 4) disebut model Botttom-Up, dan menganggap bahwa pemerintah dan sistem serta struktur sadministrasinya harus dapat beradaptasi dengan kondisi lingkungan yang cenderung mendikte perubahan dalam struktur. Lingkungan yang dimaksud meliputi faktor ekonomi, politik, budaya, atau sosial, dan logika yang mendasari pendekatan ini relatif mirip. Struktur harus beradaptasi dengan lingkungan untuk bertahan dan terus keberadaannya, serta untuk mengembangkan pola-pola organisasi yang fungsional untuk pemenuhan tujuan kolektifnya.

Model pertama dalam Pendekatan BottomUp menurut Farazmand (2002: 4) ialah model ilmu politik dan administrasi publik, yakni pemerintah dan elit politik/administrasi mendeteksi inovasi atau tekanan dalam lingkungan yang memerlukan respons pemerintah. Akibatnya, struktur administrasi negara atau organisasi administrasi publik tertentu bereaksi dengan mengadopsi perubahan melalui reformasi dan reorganisasi untuk beradaptasi dengan lingkungan. Teori sistem memberikan penjelasan teoritis yang jelas dan salah satu masalah yang terkait dengan model ini adalah tidak menunjukkan kapan dan bagaimana perubahan dalam sinyal lingkungan yang diadaptasi oleh administrasi.

Selain itu, model kontingensi adalah yang paling sering digunakan dalam pendekatan lingkungan (Bottom-Up) (Lawrence dan Lorsch 
dalam Farazmand, 2002: 4). Teori sistem secara umum, dan teori kontingensi sebagai variannya, menyediakan literatur yang terbaik untuk menjelaskan model ini. Logika dari pendekatan ini adalah refleksi internal organisasi baik secara struktural maupun perilaku adalah bentuk dari kondisi lingkungan yang memengaruhi administrasi publik. Di sisi negatif, pendekatan ini adalah prediktor yang kurang baik pada struktur dan perilaku organisasi, dan menganggap bahwa pemerintah dan organisasi mereka dapat mengubah kondisi lingkungan mereka mencapai tujuannya.

Sedangkan model yang ketiga menurut Farazmand (2002: 5) ialah model ekologi populasi. Model ini cenderung untuk menjelaskan hubungan antara organisasi dan lingkungannya dengan melihat dua perangkat yang berbeda dari lingkungan yang harus diadaptasi oleh organisasi: (1) Ekologi organisasi (Aldrich, 1979; Carroll, 1984); (2) Lingkungan umum yang lebih luas di tempat semua organisasi lainnya beroperasi. Untuk bertahan hidup, semua organisasi mengalami siklus kelahiran, kematian, dan kelangsungan hidup, dan organisasi harus menjaga keseimbangan ekosistem mereka. Organisasi harus menemukan ceruk di lingkungan mereka dan bertahan hidup, sebagai kekuatan bersaing dari lingkungan ekologi yang menentukan keberadaan mereka (Farazmand, 1994).

Meskipun model ekologi tidak sering diterapkan dalam reformasi sektor publik, tetapi dapat memberikan kita pemahaman tentang evolusi dan keberlanjutan organisasi tertentu dalam lingkungan, dan bagaimana organisasi sektoral mencoba untuk menemukan ceruk dalam lingkungan untuk pertumbuhan dan perkembangannya.

Walaupun tidak sepopuler pendekatan proses, pendekatan dampak lebih tepat diterapkan pada pengembangan kapasitas; dominasi organisasi yang terlibat lebih dominan organisasi nonpemerintah seperti lembaga swadaya masyarakat dan swasta. Hal ini bukan berarti peran pemerintah tidak diperlukan, namun yang terpenting ketersediaan pihakpihak yang memiliki kepentingan dan keinginan untuk merubah kondisi dan membantu pemerintah pada era governance jauh lebih penting mengingat keterbatasan lembaga pemerintah dalam menjalan fungsinya terkait penyandang kebutuhan khusus terutama bagi anak autis.

Reformasi administrasi menurut Caiden (1991) bertujuan untuk tidak menimbulkan biaya mahal, lebih efisien, memfasilitasi program dan menghasilkan pelayanan yang berkualitas, lebih efektif, meningkatkan etika, akuntabilitas dan transparansi dalam pemerintahan. Sedangkan tujuan reformasi administrasi menurut Mosher (Zauhar, 2007: 13) meliputi: perubahan inovatif terhadap kebijakan dan program pelaksanaan, meningkatkan efektivitas administrasi, meningkatkan kualitas personel, dan melakukan antisipasi terhadap kemungkinan kritik dan keluhan dari pihak luar.

Caiden (Zauhar, 2007: 8) menjelaskan bahwa tujuan reformasi administrasi adalah untuk memberikan saran tentang bagaimana caranya agar individu, kelompok, dan institusi, dapat mencapai tujuan lebih efektif, ekonomis, dan lebih cepat. Penguatan di level individu, kelompok dan institusi tersebut pada prinsipnya terkait dengan pengembangan kapasitas. Di sisi lain, dengan menerapkan reformasi administrasi, menurut Caiden (2001: 656) akan berkontribusi inisiatif sektor swasta, pengaturan organisasi secara mandiri, dan penyediaan alternatif pilihan konsumen. Selain sektor swasta, kontribusi inisiatif juga berkembang di masyarakat.

Terkait dengan pilihan strategi reformasi yang tepat untuk dilaksanakan di sebuah negara, Hahn-Been Lee (1976: 118) mengategorisasikan menjadi tiga kelompok, yakni: reformasi prosedural yang bertujuan untuk meningkatkan tatanan kemasyarakatan, reformasi teknis yang bertujuan untuk meningkatkan metode administrasi, dan reformasi terprogram yang bertujuan meningkatkan kinerja administrasi. Reformasi administrasi yang bertujuan untuk meningkatkan tatanan kehidupan masyarakat (improved order) biasanya terjadi di negaranegara yang baru saja mengalami pergantian pemerintahan secara cepat dan drastis akibat pergantian rezim, misalnya negara yang baru merdeka dari proses kolonisasi, sehingga perlu 
adanya tatanan administrasi pemerintahan baru yang dapat menjamin tatanan masyarakat lebih stabil. Untuk memperbaiki tatanan masyarakat tersebut maka jenis reformasi administrasi yang dilaksanakan berupa reformasi prosedural dengan merancang prosedur rutin pemerintahan untuk menjalankan pembangunan.

Jika reformasi administrasi yang bertujuan untuk meningkatkan tatanan kehidupan masyarakat lebih disebabkan karena keinginan untuk memperbaiki prosedur yang ada, maka reformasi administrasi teknikal bertujuan untuk meningkatkan kualitas metode administrasi lama yang sebelumnya berlaku, lebih disebabkan untuk merespon tekanan atau rangsangan eksternal. Motivasi rangsangan eksternal tersebut bisa karena adanya keingintahuan intelektual atas metode baru tersebut atau karena adanya motivasi kekuasaan dan kontrol. Apa pun motivasinya, teknik reformasi administrasi yang lebih modern tersebut digunakan untuk mendorong proses modernisasi.

Adapun reformasi administrasi terprogram yang dilaksanakan dengan tujuan untuk meningkatkan kinerja pemerintahan, diimplementasikan melalui strategi reformasi program-program pemerintahan. Berbeda dengan reformasi administrasi yang sifatnya prosedural dan teknik, fokus reformasi terprogram atau terencana adalah memperbaiki substansi administrasi, misalnya bukan sekadar merubah efisiensi ekonomi tetapi bagaimana dapat menjamin efektivitas pencapaian sasaran sehingga dapat menghasilkan peningkatan kinerja lebih baik. Hahn-Been Lee (1976) mengatakan reformasi administrasi yang bertujuan untuk meningkatkan kinerja program hanya datang ketika pemerintah di negara berkembang mulai serius untuk membangun ekonomi dan sosial masyarakat.

\section{Karakter Bangsa}

Karakter bangsa dapat dimaknai sebagai sikap dan perilaku warga negara yang sesuai dengan kaidah-kaidah yang berlaku dalam kehidupan bermasyarakat. De Vos dalam (Budimansyah dan Suryadi, 2008: 77-78) menjelaskan bahwa karakter bangsa sebagai 'the enduring personality characteristics and unique life style found among the populations particular nations state'. Pernyataan ini menjelaskan bahwa karakter bangsa digunakan untuk mendeskripsikan ciri-ciri kepribadian dan gaya hidup yang khas dan dapat ditemui pada populasi masyarakat negara tertentu. Karena terkait dengan masalah kepribadian yang merupakan bagian dari aspek kejiwaan maka diakui oleh De Vos bahwa dalam konteks perilaku, karakter bangsa dianggap sebagai istilah yang abstrak yang terikat oleh aspek budaya dan termasuk dalam mekanisme psikologis yang menjadi karakteristik masyarakat tertentu (Yunus, 2013: 71).

Untuk dapat dijadikan dasar dalam membentuk karakter bangsa, Budaya yang berkembang di masyarakat perlu melalui proses transformasi nilai. Transformasi nilai adalah usaha yang dilakukan untuk tetap melestarikan atau mengembangkan nilai-nilai yang terkandung dalam budaya agar budaya tersebut dapat menjawab kompleksitas permasalahan yang dialami oleh mansyarakat. Dengan adanya transformasi nilai-nilai budaya tersebut, masyarakat dapat mengetahui nilai-nilai yang menjadi acuan dalam hidup agar mereka dapat menyesuaikan dengan perkembangan yang ada tanpa melupakan nilai-nilai dasar yang terkandung dalam budaya lokalnya (Yunus, 2013).

Transformasi nilai menurut Hoffman (Hakam, 2007: 156) yaitu proses internalisasi yang berfungsi sebagai transisi dari orientasi eksternal ke orientasi internal dalam hal nilai dan moral. internalisasi yang awalnya eksternal atau berdasarkan norma dan nilai budaya masyarakat, melakukan pergeseran orientasi menuju internal, yakni orientasi diri sendiri dalam memotivasi tindakan seseorang yang bermuara pada prilaku. Dalam kajian budaya, proses internalisasi memainkan peranan yang penting. Jika sosialisasi budaya lebih bersifat horizontal dan kuantitatif kepada banyak orang, namun proses internalisasi budaya lebih bersifat vertikal dan kualitatif pada diri seseorang (Ndraha, 1997).

\section{Simpulan}

Caiden dalam Nasirin (2013) menjelaskan bahwa reformasi administrasi di sektor publik 
berkaitan erat dengan lingkungan budaya tertentu, sehingga tidak ada satu perspektif pun yang dapat dianggap lebih baik daripada yang lain. Selain itu, pendekatan reformasi administrasi publik bersifat terikat pada budaya, sehingga tidak dapat langsung dapat diterapkan oleh setiap negara dengan begitu saja. Dari pernyataan tersebut, dapat dipahami bahwa perubahan atau perbaikan yang terjadi dalam administrasi tidak dapat dipisahkan dari nilai-nilai budaya yang dipahami dan diyakini oleh masyarakat tertentu. Akumulasi dari nilainilai budaya yang dijadikan acuan bagi warga negara dalam berprilaku memiliki kaitan yang erat dengan karakter bangsa.

Nilai-nilai budaya yang luhur seyogianya harus mendapat menjadi sources of ethic bagi proses reformasi administrasi. Ada sebuah prinsip yang harus menjadi perhatian dalam hal ini yaitu bagaimana nilai nilai budaya tersebut menjadi jiwa dalam pelaksanaan reformasi administrasi yang dijalankan, dan apakah reformasi administrasi yang dijalankan telah berpedoman pada prinsip-prinsip nilai budaya?

\section{DAFTAR PUSTAKA}

Aldrich, H.E. 1979. Organizations and Environments. Englewood Cliffs, NJ: Prentice-Hall.

Budimansyah, D., Suryadi, K., 2008. PKn dan Masyarakat Multikultural. Bandung: Sekolah Pascasarjana Program Pendidikan Kewarganegaraan Universitas Pendidikan Indonesia.

Caiden, G. E. 2001. Administrative Reform, in Ali Farazmand, Comparative and Development Public Administration, pp. 665 - 667.

------. 1991. Administrative Reform Comes of Age. New York: Walter de Gruyter.

------. 1969. Administrative Reform, Chicago: Aldine.

Carroll, G.R. 1984. "Organizational Ecology." Annual Review of Sociology, 10: 71-93.

Farazmand, Ali. 2002. Administrative Reform in Developing Nations. USA: Greenwood Publishing Group Inc.
1994. "Organization Theory: An Overview and Appraisal." In Ali Farazmand, ed., Modern Organizations: Administrative Theory in Contemporary Society.Westport, CT: Praeger, pp. 1-51.

Hahn-Been, Lee. 1976. Bureaucratic Models and Administrative Reform, in The Management of Change in Government. A. F. Leemans (ed), Martinus Nijhoff. The Hague: Institute of Social Studies.

Hakam, A.K. 2007. Bunga Rampai Pendidikan Nilai. Bandung: Universitas Pendidikan Indonesia.

Imawan, Riswanda, Makna Reformasi: Salah Kaprah. Kedaulatan Rakyat. 22 Juni, 1999, Yogyakarta.

Nasirin, Chairun, 2013. Reformasi Administrasi Publik, Sebuah Kajian Konseptual, Jurnal Ilmiah Administrasi Publik dan Pembangunan, 4 (2): 92-99.

Ndraha, Taliziduhu, 1997. Budaya Organisasi. Jakarta: Rineka Cipta.

Peter, B. Guy, 1994. "Government Reorganization: A Theoretical Analysis." In Ali Farazmand, ed., Modern Organizations: Administrative Theory in Contemporary Society. Westport, CT: Praeger.

Politt, C., 1984. Manipulating the Machine: Changing the Patterns of Ministerial Departments,1960-83. London: Allen \& Unwin.

Samonte, A.G., 1970, 'Patterns and Trends in Administrative Reform', in Lee, H-B. and Samonte, A.G., eds, Administrative Reforms in Asia, Manila: EROPA, pp. 287302.

Yunus, Rasid, 2013. Transformasi Nilai-nilai Budaya Lokal sebagai Upaya Pembangunan Kataklter Bangsa, Penelitian Studi Kasus Budaya Huluya di Kota Gorontalo, Jurnal Penelitian Pendidikan, 4(1): 65-77.

Wallis, M. 1993. Bureaucracy: Its Roles In Third World Development. Hong Kong: Macmillan. 
Bambang Irawan, Reformasi Administrasi dan Karakter Bangsa: Sebuah Kajian Konseptual

Zauhar, Soesilo. 2007, Reformasi Administrasi:

Ketiga, Jakarta: Bumi Aksara. Konsep, Dimensi dan Strategi. Cetakan 